Article

\title{
Bioactive Cembrane-Based Diterpenoids from the Soft Coral Sinularia triangular
}

\author{
Jui-Hsin Su $^{1,2, *}$ and Zhi-Hong Wen ${ }^{3}$
}

1 National Museum of Marine Biology \& Aquarium, Pingtung 944, Taiwan

2 Graduate Institute of Marine Biotechnology, National Dong Hwa University, Pingtung 944, Taiwan

3 Department of Marine Biotechnology and Resources, National Sun Yat-sen University, Kaohsiung 804, Taiwan; E-Mail: wzh@ mail.nsysu.edu.tw

* Author to whom correspondence should be addressed; E-Mail: x2219@ nmmba.gov.tw.

Received: 25 April 2011; in revised form: 19 May 2011 / Accepted: 26 May 2011 /

Published: 27 May 2011

\begin{abstract}
Chemical examination of the Taiwanese soft coral Sinularia triangular led to the isolation of five cembrane-based diterpenoids $\mathbf{1 - 5}$, including two new metabolites, triangulenes A (1) and B (2). The structures of the new metabolites were determined on the basis of extensive spectroscopic analysis, particularly mass spectroscopy and 2D NMR $\left({ }^{1} \mathrm{H}-{ }^{1} \mathrm{H}\right.$ COSY, HMQC, HMBC, and NOESY) spectroscopy. Metabolites $\mathbf{3}$ and $\mathbf{5}$ exhibited moderate cytotoxicity to human tumor cell lines CCRF-CEM and DLD-1. Furthermore, 3-5 displayed significant in vitro anti-inflammatory activity in lipopolysaccharidestimulated RAW264.7 macrophage cells by inhibiting the expression of the iNOS protein. Metabolites 4 and 5 also effectively reduced the expression of the COX-2 protein in the macrophages.
\end{abstract}

Keywords: soft coral; Sinularia triangular; cytotoxicity; anti-inflammatory

\section{Introduction}

Our previous chemical examination of soft corals of the genus Sinularia led to the isolation and identification of various oxygenated cembrane-type metabolites [1-5]. Some of these metabolites exhibit anti-inflammatory activity [2-4] and/or cytotoxicity to the growth of some cancer cell lines [1]. Our ongoing research to discover bioactive metabolites from the soft coral Sinularia triangular (Tixier-Durivault, 1970; family Alcyoniidae) (Figure 1) led to the isolation of two new 
cembrane-based diterpenoids, triangulenes A (1) and B (2), along with three known metabolites, sinularin (3) [6], dihydrosinularin (4) [6], and (-)14-deoxycrassin (5) [7]. The structures of 1 and 2 were established by extensive spectroscopic analysis, including 2D NMR spectroscopy. The cytotoxicity of 1-5 to the human tumor cell lines CCRF-CEM (T-cell acute lymphoblastic leukemia) and DLD-1 (colon adenocarcinoma) was studied, and the ability of 1-5 to inhibit the expression of the pro-inflammatory iNOS (inducible nitric oxide synthase) and COX-2 (cyclooxygenase-2) proteins in lipopolysaccharide (LPS)-stimulated RAW264.7 macrophage cells was also evaluated.

Figure 1. Soft coral Sinularia triangular.

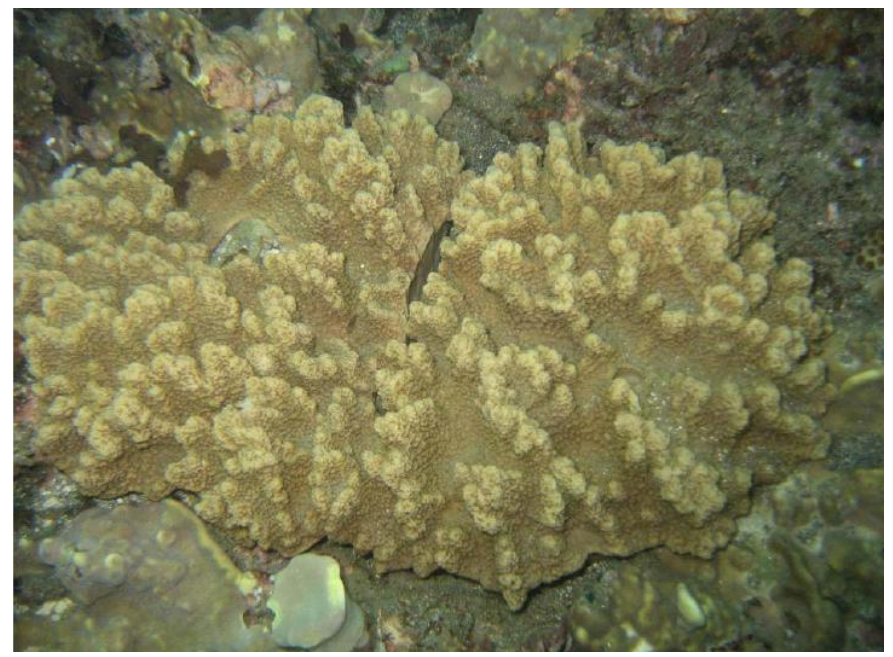

\section{Results and Discussion}

Frozen samples of $S$. triangular were extracted with EtOAc. The dry EtOAc extracts were fractionated by silica gel gravity column chromatography, and the eluted fractions were further purified by HPLC to yield cembranoids $\mathbf{1}-\mathbf{5}$ (Figure 2).

Figure 2. Structures of 1-5.

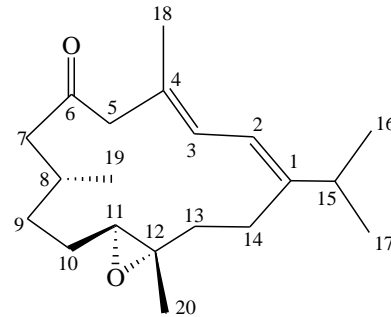

1

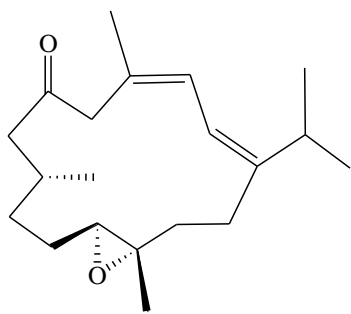

2

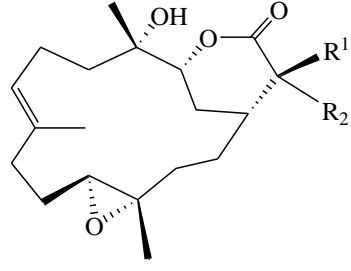

$3 \quad \mathrm{R}^{1}=\mathrm{R}^{2}=\mathrm{CH}_{2}$

$4 \mathrm{R}^{1}=\mathrm{CH}_{3}, \mathrm{R}^{2}=\mathrm{H}$

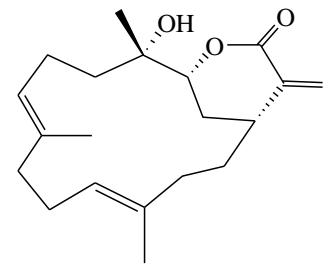

5 
Table 1. ${ }^{1} \mathrm{H}$ and ${ }^{13} \mathrm{C}$ NMR data for $\mathbf{1}$ and 2.

\begin{tabular}{|c|c|c|c|c|}
\hline & \multicolumn{2}{|l|}{1} & \multicolumn{2}{|l|}{2} \\
\hline & ${ }^{1} \mathrm{H}^{a}$ & ${ }^{13} \mathrm{C}^{b}$ & ${ }^{1} \mathrm{H}^{a}$ & ${ }^{13} \mathrm{C}^{b}$ \\
\hline 1 & & $148.3(\mathrm{C})$ & & $146.7(\mathrm{C})$ \\
\hline 2 & $6.06 \mathrm{~d}(10.8)$ & $118.2(\mathrm{CH})$ & $6.19 \mathrm{~d}(10.8)$ & $118.7(\mathrm{CH})$ \\
\hline 3 & $6.15 \mathrm{~d}(10.8)$ & $125.7(\mathrm{CH})$ & $6.29 \mathrm{~d}(10.8)$ & $124.4(\mathrm{CH})$ \\
\hline 4 & & $129.3(\mathrm{C})$ & & $130.5(\mathrm{C})$ \\
\hline 5 & $3.20 \mathrm{~d}(13.6) ; 3.06 \mathrm{~d}(13.6)$ & $54.7\left(\mathrm{CH}_{2}\right)$ & $3.90 \mathrm{~d}(13.6) ; 2.70 \mathrm{~d}(13.6)$ & $48.9\left(\mathrm{CH}_{2}\right)$ \\
\hline 6 & & $209.8(\mathrm{C})$ & & $208.0(\mathrm{C})$ \\
\hline 7 & $2.54 \mathrm{dd}(13.2,8.4) ; 2.17 \mathrm{~m}$ & $51.2\left(\mathrm{CH}_{2}\right)$ & $2.52 \mathrm{~m} ; 2.12 \mathrm{~m}$ & $52.4\left(\mathrm{CH}_{2}\right)$ \\
\hline 8 & $2.03 \mathrm{~m}$ & $31.2(\mathrm{CH})$ & $1.83 \mathrm{~m}$ & $32.0(\mathrm{CH})$ \\
\hline 9 & $1.48 \mathrm{~m} ; 1.18 \mathrm{~m}$ & $33.1\left(\mathrm{CH}_{2}\right)$ & $1.31 \mathrm{~m} ; 1.14 \mathrm{~m}$ & $33.3\left(\mathrm{CH}_{2}\right)$ \\
\hline 10 & $1.92 \mathrm{~m} ; 1.14 \mathrm{~m}$ & $26.4\left(\mathrm{CH}_{2}\right)$ & $1.88 \mathrm{~m} ; 1.09 \mathrm{~m}$ & $26.4\left(\mathrm{CH}_{2}\right)$ \\
\hline 11 & $2.71 \mathrm{dd}(8.4,4.0)$ & $62.7(\mathrm{CH})$ & $2.49 \mathrm{~m}$ & $64.4(\mathrm{CH})$ \\
\hline 12 & & $61.5(\mathrm{C})$ & & $60.6(\mathrm{C})$ \\
\hline 13 & $2.15 \mathrm{~m} ; 1.32 \mathrm{~m}$ & $36.7\left(\mathrm{CH}_{2}\right)$ & $2.12 \mathrm{~m} ; 1.36 \mathrm{~m}$ & $36.7\left(\mathrm{CH}_{2}\right)$ \\
\hline 14 & $2.37 \mathrm{~m} ; 2.28 \mathrm{~m}$ & $25.9\left(\mathrm{CH}_{2}\right)$ & $2.73 \mathrm{~m} ; 2.12 \mathrm{~m}$ & $25.7\left(\mathrm{CH}_{2}\right)$ \\
\hline 15 & $2.35 \mathrm{~m}$ & $32.2(\mathrm{CH})$ & $2.35 \mathrm{~m}$ & $30.8(\mathrm{CH})$ \\
\hline 16 & $1.06 \mathrm{~d}(7.2)$ & $22.6\left(\mathrm{CH}_{3}\right)$ & $1.18 \mathrm{~d}(6.8)$ & $20.6\left(\mathrm{CH}_{3}\right)$ \\
\hline 17 & $1.08 \mathrm{~d}(7.6)$ & $22.1\left(\mathrm{CH}_{3}\right)$ & $1.02 \mathrm{~d}(6.8)$ & $23.4\left(\mathrm{CH}_{3}\right)$ \\
\hline 18 & $1.89 \mathrm{~s}$ & $18.2\left(\mathrm{CH}_{3}\right)$ & $1.93 \mathrm{~s}$ & $25.1\left(\mathrm{CH}_{3}\right)$ \\
\hline 19 & $0.93 \mathrm{~d}(6.8)$ & $19.5\left(\mathrm{CH}_{3}\right)$ & $0.85 \mathrm{~d}(6.4)$ & $19.2\left(\mathrm{CH}_{3}\right)$ \\
\hline 20 & $1.20 \mathrm{~s}$ & $17.6\left(\mathrm{CH}_{3}\right)$ & $1.23 \mathrm{~s}$ & $16.3\left(\mathrm{CH}_{3}\right)$ \\
\hline
\end{tabular}

The HRESIMS spectrum of triangulene A (1) contained a molecular ion peak consistent with the molecular formula $\mathrm{C}_{20} \mathrm{H}_{32} \mathrm{O}_{2}$, indicating the molecule has five double-bond equivalent. A UV absorption maxima at $240 \mathrm{~nm}(\log \varepsilon=4.0)$ was attributed to double bond conjugation. The IR spectrum of 1 revealed the presence of a carbonyl functionality $\left(v_{\max }=1703 \mathrm{~cm}^{-1}\right)$. The ${ }^{13} \mathrm{C}$ NMR data of 1 showed the presence of 20 carbons (Table 1): five methyls, six $\mathrm{sp}^{3}$ methylenes, three $\mathrm{sp}^{3}$ methines (including an oxygenated carbon at $\delta 62.7$ ), two $\mathrm{sp}^{2}$ methines, and four quaternary carbons (including an oxygenated carbon at $\delta 61.5$, two olefinic carbons with resonances at $\delta 148.3$ and $\delta 129.3$, and a keto-carbonyl at $\delta 209.8$ ). The ${ }^{1} \mathrm{H}$ NMR data revealed the presence of two olefinic methine protons as doublets at $\delta 6.15$ and $\delta 6.06$. A proton signal at $\delta 2.71(1 \mathrm{H}, \mathrm{dd}, J=8.4,4.0 \mathrm{~Hz})$ that correlated with a carbon signal at $\delta 62.7$ in the HMQC spectrum of 1 was attributed to the proton of a trisubstituted epoxide. The gross planar structure of 1 was determined by detailed analysis of its 1D and 2D NMR spectra. From the ${ }^{1} \mathrm{H}-{ }^{1} \mathrm{H}$ COSY correlations (Figure 3), it was possible to establish five partial structures of consecutive proton spin systems extending from $\mathrm{H}-2$ to $\mathrm{H}-3 ; \mathrm{H}-8$ to $\mathrm{H}_{3}-19 ; \mathrm{H}_{2}-9$ to $\mathrm{H}-11 ; \mathrm{H}_{2}-13$ to $\mathrm{H}_{2}-14$; and $\mathrm{H}-15$ to $\mathrm{H}_{3}-16$ and $\mathrm{H}_{3}-17$. The following key $\mathrm{HMBC}$ correlations permitted connection of the carbon skeleton: H-2 to C-1, C-14, and C-15; H-3 to C-5; H-5 to C-4 and C-6 (carbonyl carbon); $\mathrm{H}-7$ to $\mathrm{C}-6, \mathrm{C}-8$, and $\mathrm{C}-9 ; \mathrm{H}-13$ to $\mathrm{C}-11$ and $\mathrm{C}-12 ; \mathrm{H}_{3}-16$ and $\mathrm{H}_{3}-17$ to $\mathrm{C}-1$ and C-15; $\mathrm{H}_{3}-18$ to C-3, C-4, and C-5; $\mathrm{H}_{3}-19$ to C-7, C-8, and C-9; and $\mathrm{H}_{3}-20$ to C-11, C-12, and C-13. Thus, 1 was found to possess a tetrasubstituted diene at C-1/C-2 and C-3/C-4, a ketone group at C-6, 
and a trisubstituted epoxide at $\mathrm{C}-11 / \mathrm{C}-12$. The above results indicate that $\mathbf{1}$ possessed the same molecular framework as known cembranoids 6 and 7 (Figure 4), which were isolated previously from octocorals Eunicea tourniforti [8] and Eunicea sp. [9], respectively.

Figure 3. Key ${ }^{1} \mathrm{H}-{ }^{1} \mathrm{H}$ COSY and HMBC correlations of $\mathbf{1}$.

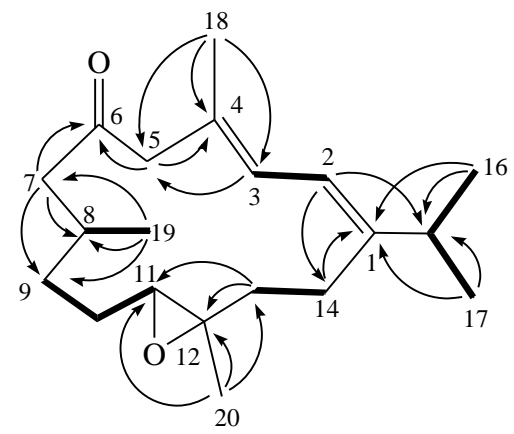

Figure 4. Structures of 6-8.

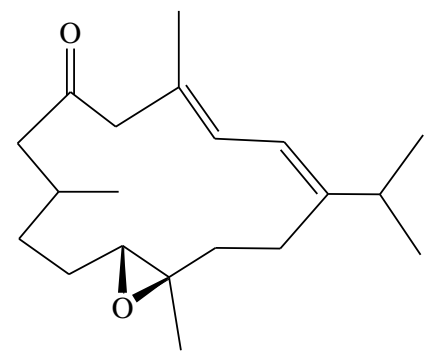

6

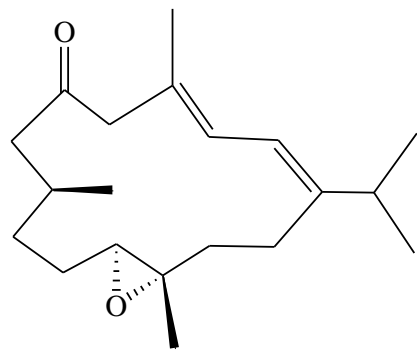

7

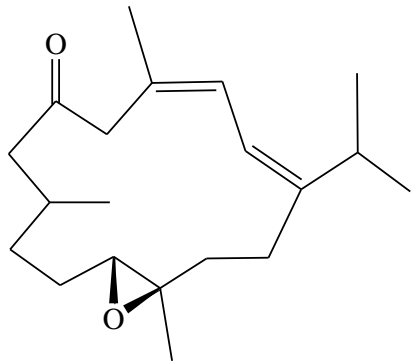

8

The relative configuration of $\mathbf{1}$ was determined from NOE correlations observed in the NOESY spectrum (Figure 5). The NOE correlations between $\mathrm{H}-2$ and methyl protons $\mathrm{H}_{3}-16$ and $\mathrm{H}_{3}-18$ and between $\mathrm{H}-3$ and $\mathrm{H}_{2}-5$ indicated $E$ configurations for the double bonds at C-1/C-2 and C-3/C-4. In addition, one proton of C-10 methylene $(\delta$ 1.92) was found to exhibit correlations with $\mathrm{H}-11$ $(\delta 2.71, \mathrm{dd}, J=8.4,4.0 \mathrm{~Hz})$ and $\mathrm{H}_{3}-19(\delta 0.93, \mathrm{~d}, J=6.8 \mathrm{~Hz})$, indicating that these protons were situated on the same face; they were assigned as $\alpha$ protons, as C-20 methyl was $\beta$-oriented at C-12, which were verified by the absence of correlation between $\mathrm{H}-11$ and $\mathrm{H}_{3}-20$. Furthermore, $\mathrm{H}_{3}-20$ correlated with protons of $\mathrm{C}-10$ ( $\delta 1.92$ and 1.14) and $\mathrm{C}-14$ ( $\delta 2.37$ and 2.28) methylenes, respectively. Consideration of molecular models found that $\mathrm{H}_{3}-20$ was reasonably close to $\mathrm{H}_{2}-10$ and $\mathrm{H}_{2}-14$ when $\mathrm{H}_{3}-20$ was $\beta$-oriented. Based on the above findings, the structure of $\mathbf{1}$, including its relative configuration was established, and the chiral centers for 1 were assigned as $8 S^{*}, 11 S^{*}$, and $12 S^{*}$. Furthermore, the chemical shifts of 1 were shifted downfield at C-7 $\left(\Delta \delta_{C}+1.7 \mathrm{ppm}\right)$ and C-8 $\left(\Delta \delta_{C}+2.5 \mathrm{ppm}\right)$ and upfield at $\mathrm{C}-19\left(\Delta \delta_{C}-0.8 \mathrm{ppm}\right)$ relative to the corresponding chemical shifts of 7 . On the basis of the above findings, we determined the relative structure of $\mathbf{1}$, which was determined to be the C-8 epimer of $\mathbf{7}$. 
Figure 5. Selective NOESY correlations of $\mathbf{1}$ and 2.

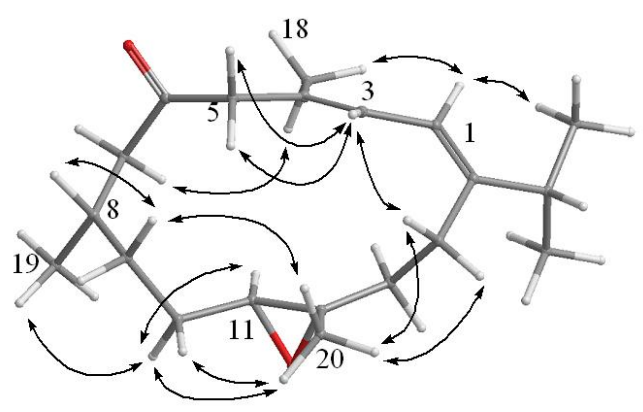

1

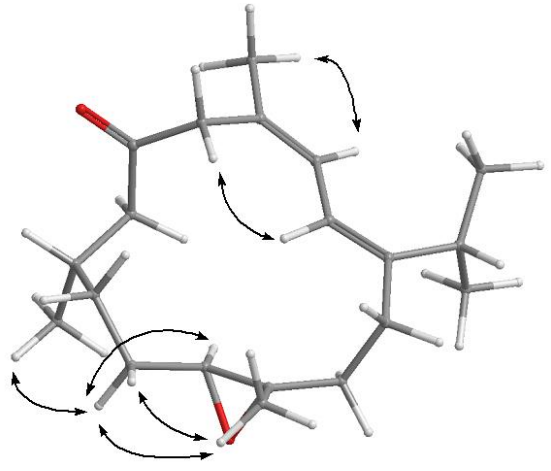

2

Triangulene $\mathrm{B}(2)$ had the same molecular formula $\left(\mathrm{C}_{20} \mathrm{H}_{32} \mathrm{O}_{2}\right)$ as $\mathbf{1}$, as indicated by HRESIMS and NMR spectra (Table 1). Comparison of the ${ }^{1} \mathrm{H}$ and ${ }^{13} \mathrm{C}$ NMR data of 2 with those of $\mathbf{1}$ revealed that the two compounds possessed similar structures. The trisubstituted double bonds at C-1/C-2 and C-3/C-4 of 2 had $Z$ geometries, as indicated by NOE interactions (Figure 5) between $\mathrm{H}-3(\delta 6.29)$ and $\mathrm{H}_{3}-18$ ( $\delta$ 1.93) and between H-2 ( $\delta$ 6.19) and H-5 ( $\delta$ 3.90). After determining the structure of 2 , we discovered that its planar structure has been obtained previously as diterpenoid $\mathbf{8}$ from the octocoral Eunicea sp. [8]. Furthermore, we found that the NMR data for $\mathbf{2}$ were similar to those of $\mathbf{8}$, except that C-7 and C-8 of 2 were shifted markedly downfield $\left(\Delta \delta_{C}+3.9 \mathrm{ppm}\right.$ and $\Delta \delta_{\mathrm{C}}+3.6 \mathrm{ppm}$, respectively) relative to the corresponding carbons of $\mathbf{8}$. Further analysis of other NOE interactions revealed that $\mathbf{1}$ and 2 possessed the same relative configurations at C-8, C-11, and C-12. Thus, the structure of 2 was established unambiguously.

Figure 6. Immunoblot analysis of the effects of 1-5 $(10 \mu \mathrm{M})$ on the expression of the iNOS and COX-2 proteins of RAW264.7 macrophage cells: (A) Immunoblots of iNOS and $\beta$ actin and (B) immunoblots of COX-2 and $\beta$-actin. The relative intensity for the cells stimulated with LPS alone was set at $100 \%$. Band intensities were quantified by densitometry and are indicated as percentages relative to the intensities for the LPS-stimulated cells. Western blotting with $\beta$-actin was performed to verify that equivalent amounts of protein were loaded in each lane. Values represent mean $\pm \operatorname{SEM}(n=6)$. *Significantly different from the values for cells stimulated with LPS alone $\left({ }^{*} P<0.05\right)$. ${ }^{a}$ Stimulated with LPS alone; ${ }^{b}$ stimulated with LPS in the presence of $\mathbf{1}-\mathbf{5}$.
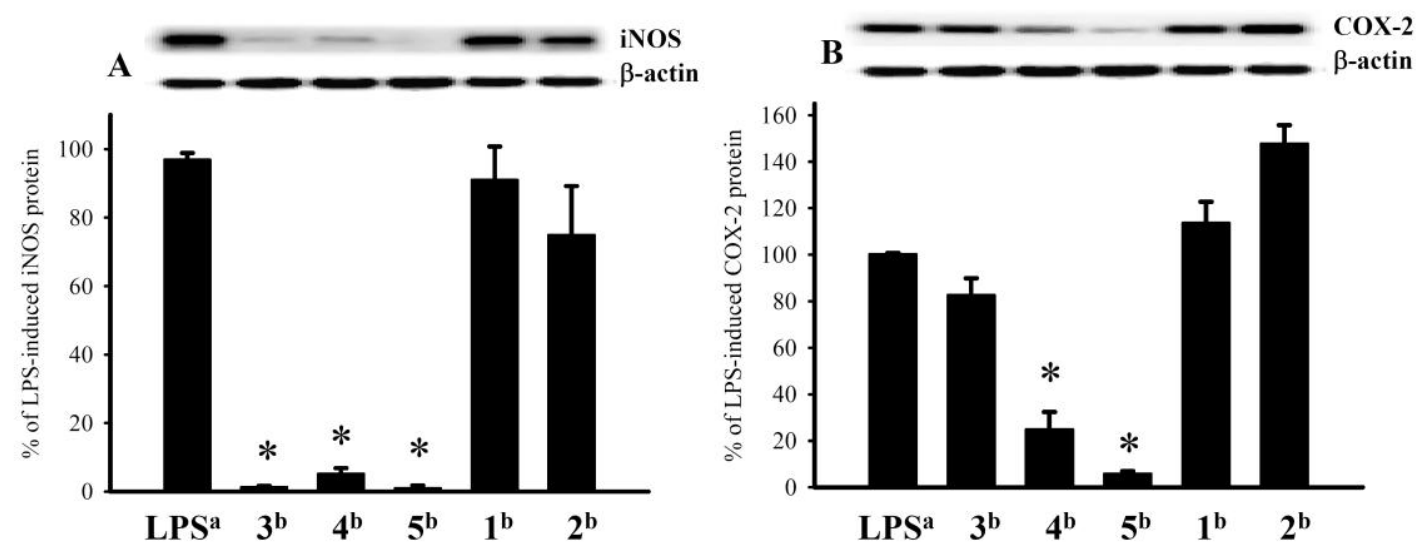
Study of the cytotoxicity of diterpenoids 1-5 to human tumor cell lines CCRF-CEM and DLD-1 showed that $\mathbf{3}$ and $\mathbf{5}$ moderately inhibited the growth of the tested cell lines (the $\mathrm{ED}_{50}$ values were 26.0 and $37.1 \mu \mathrm{M}$ for 3 and 29.8 and $32.2 \mu \mathrm{M}$ for $\mathbf{5}$ for CCRF-CEM and DLD-1, respectively). The in vitro anti-inflammatory effects of 1-5 were also tested. The inhibition of LPS-stimulated upregulation of the pro-inflammatory proteins iNOS and COX-2 in RAW264.7 macrophage cells was measured by immunoblot analysis. At a concentration of $10 \mu \mathrm{m}, 3-5$ reduced the levels of the iNOS protein to $1.2 \pm 0.3 \%, 5.1 \pm 1.6 \%$, and $0.9 \pm 0.7 \%$, respectively, of the levels in control cells stimulated with LPS alone (set at 100\%). At the same concentration, $\mathbf{4}$ and $\mathbf{5}$ markedly reduced the levels of COX-2 to $24.9 \pm 7.4 \%$ and $5.9 \pm 1.0 \%$, respectively, relative to controls (Figure 6).

\section{Experimental Section}

\subsection{General Experimental Procedures}

Melting points were measured on Fargo apparatus and are uncorrected. Optical rotation values were measured with a Jasco P-1010 digital polarimeter. Ultraviolet spectra were recorded on a Jasco V-650 spectrophotometer. IR spectra were obtained with a Varian Digilab FTS 1000 FT-IR spectrophotometer. NMR spectra were recorded with a Varian Mercury Plus 400 FT-NMR, at $400 \mathrm{MHz}$ for ${ }^{1} \mathrm{H}$ NMR and $100 \mathrm{MHz}$ for ${ }^{13} \mathrm{C} \mathrm{NMR}$, in $\mathrm{CDCl}_{3}$. ESIMS and HRESIMS data were recorded with a Bruker APEX II mass spectrometer. Silica gel 60 (230-400 mesh; Merck, Darmstadt, Germany) was used for column chromatography. Gravity column chromatography was performed on silica gel (230-400 mesh; Merck). TLC was carried out on precoated Kieselgel 60 F254 (0.2 mm; Merck), and spots were visualized by spraying with $10 \% \mathrm{H}_{2} \mathrm{SO}_{4}$ solution followed by heating. HPLC was performed on a system comprising a Hitachi L-7100 pump, a Hitachi photodiode array detector L-7455, and a Rheodyne 7725 injection port. A semi-preparative reverse-phase column (Hibar $250 \times 10 \mathrm{~mm}$, LiChrospher $100 \mathrm{RP}-18 \mathrm{e}, 5 \mu \mathrm{m}$, Merck) and a preparative normal-phase column (Hibar $250 \times 21 \mathrm{~mm}$, Si-60 column, $7 \mu \mathrm{m}$, Merck) were used for HPLC.

\subsection{Animal Material}

The marine soft coral $S$. triangular (specimen No. 200807-15) was collected by scuba divers at a depth of around $10 \mathrm{~m}$ off the coast of Taitung County, Taiwan, in July 2008, and the samples were frozen immediately after collection. A voucher sample was deposited at the Department of Marine Biotechnology and Resources, National Sun Yat-sen University, Taiwan.

\subsection{Extraction and Separation}

The frozen bodies of $S$. triangular $(1.2 \mathrm{~kg}$, wet weight) were minced and exhaustively extracted with EtOAc $(1 \mathrm{~L} \times 5)$. The combined EtOAc extracts $(15.5 \mathrm{~g})$ were subjected to silica gel column chromatography with elution by EtOAc in $n$-hexane (0-100\%, stepwise) followed by $100 \%$ acetone; and the fractions were pooled on the basis of TLC analysis to yield 17 fractions. Fraction 8 (265 mg), which eluted with $n$-hexane-EtOAc (10:1), was subjected to silica gel column chromatography with gradient elution ( $n$-hexane-acetone, 12:1 to 6:1) to afford five subfractions (A1-A5). Subfraction A2 $\left(20 \mathrm{mg}\right.$ ) was subjected to reverse-phase $\mathrm{HPLC}$ with $\mathrm{MeOH}-\mathrm{H}_{2} \mathrm{O}(5: 1)$ elution to afford $\mathbf{1}$ (2.5 mg) and 
2 (2.0 mg). Subfraction A3 (90 mg) was subjected to normal-phase HPLC using $n$-hexane-acetone $(10: 1)$ to afford $5(50.3 \mathrm{mg})$. Fraction $11(160 \mathrm{mg})$, which eluted with $n$-hexane-EtOAc (5:1), was subjected to silica gel column chromatography with gradient elution ( $n$-hexane-acetone, 8:1 to 5:1) to yield six subfractions (B1-B6). Subfraction B3 was subjected to normal-phase HPLC with $n$-hexane-acetone (7:1) elution to afford $3(20.5 \mathrm{mg})$ and $4(10.8 \mathrm{mg})$.

Triangulene A (1): colorless oil; $[\alpha]^{25}{ }_{\mathrm{D}}+70.8\left(c 0.5, \mathrm{CHCl}_{3}\right)$; IR (neat) $v_{\max } 2961,2928,1703,1456$, 1385, and $1261 \mathrm{~cm}^{-1}$; UV (MeOH) $\lambda_{\max } 240(\log \varepsilon=4.0) ;{ }^{13} \mathrm{C}$ and ${ }^{1} \mathrm{H}$ NMR data, see Table 1; ESIMS $m / z 327[\mathrm{M}+\mathrm{Na}]^{+}$; HRESIMS $m / z 327.2302[\mathrm{M}+\mathrm{Na}]^{+}\left(\right.$calcd for $\mathrm{C}_{20} \mathrm{H}_{32} \mathrm{O}_{2} \mathrm{Na}, 327.2300$ ).

Triangulene B (2): colorless oil; $[\alpha]^{25}{ }_{\mathrm{D}}+50.6\left(c 0.5, \mathrm{CHCl}_{3}\right)$; IR (neat) $v_{\max } 2959,2928,1709,1460$, and $1385 \mathrm{~cm}^{-1}$; UV $(\mathrm{MeOH}) \lambda_{\max } 239(\log \varepsilon=3.8) ;{ }^{13} \mathrm{C}$ and ${ }^{1} \mathrm{H}$ NMR data, see Table 1; ESIMS $m / z 327[\mathrm{M}+\mathrm{Na}]^{+}$; HRESIMS $m / z$ 327.2301 [M+ Na] ${ }^{+}\left(\right.$calcd for $\mathrm{C}_{20} \mathrm{H}_{32} \mathrm{O}_{2} \mathrm{Na}, 327.2300$ ).

Sinularin (3): white powder; mp $151-153{ }^{\circ} \mathrm{C}$; $[\alpha]^{25}{ }_{\mathrm{D}}-120\left(\mathrm{c} 0.5, \mathrm{CHCl}_{3}\right)$; ESIMS $\mathrm{m} / z \quad 357$ $[\mathrm{M}+\mathrm{Na}]^{+}[6]$.

Dihydrosinularin (4): white powder; mp $116-118{ }^{\circ} \mathrm{C}$; $[\alpha]^{25}-42\left(c 0.3, \mathrm{CHCl}_{3}\right)$; ESIMS $\mathrm{m} / z, 359$ $[\mathrm{M}+\mathrm{Na}]^{+}[6]$.

(-)14-Deoxycrassin (5): colorless oil; $[\alpha]_{\mathrm{D}}^{25}-15\left(c\right.$ 1.0, $\left.\mathrm{CHCl}_{3}\right)$; ESIMS $m / z, 341[\mathrm{M}+\mathrm{Na}]^{+}[7]$.

\subsection{Cytotoxicity Testing}

The cytotoxicity of 1-5 to CCRF-CEM and DLD-1 tumor cells was evaluated by means of the tetrazolium-based colorimetric assay [10,11]. As a positive control, we employed doxorubicin, which exhibited cytotoxicity to CCRF-CEM and DLD-1 cells with ED $_{50}$ values of 0.57 and $0.25 \mu \mathrm{m}$, respectively.

\subsection{In Vitro Anti-Inflammatory Assay}

A macrophage (RAW264.7) cell line was purchased from ATCC. We measured the in vitro anti-inflammatory activities of $\mathbf{1}-\mathbf{5}$ by examining the inhibition of LPS-simulated upregulation of the iNOS (inducible nitric oxide synthetase) and COX-2 (cyclooxygenase-2) proteins in macrophages using western blotting analysis [12,13].

\section{Acknowledgements}

This research was supported by grants from the National Museum of Marine Biology \& Aquarium and the National Science Council (NSC 99-2320-B-291-001), Taiwan, awarded to J.-H. Su.

\section{References}

1. Su, J.-H.; Ahmed, A.F.; Sung, P.-J.; Chao, C.-H.; Kuo, Y.-H.; Sheu, J.-H. Manaarenolides A-I, new diterpenoids from the soft coral Sinularia manaarensis. J. Nat. Prod. 2006, 69, 1134-1139.

2. Lu, Y.; Huang, C.-Y.; Lin, Y.-F.; Wen, Z.-H.; Su, J.-H.; Kuo, Y.-H.; Chiang, M.Y.; Sheu, J.-H. Anti-inflammatory cembranoids from the soft corals Sinularia querciformis and Sinularia granosa. J. Nat. Prod. 2008, 71, 1754-1759. 
3. Chen, B.-W.; Chao, C.-H.; Su, J.-H.; Huang, C.-Y.; Dai, C.-F.; Wen, Z.-H.; Sheu, J.-H. A novel symmetric sulfur-containing biscembranoid from the Formosan soft coral Sinularia flexibilis. Tetrahedron Lett. 2010, 44, 5764-5766.

4. Lu, Y.; Su, J.-H.; Huang, C.-Y.; Liu, Y.-C.; Kuo, Y.-H.; Wen, Z-H.; Hsu, C.-H.; Sheu, J.-H. Cembranoids from the Soft Corals Sinularia granosa and Sinularia querciformis. Chem. Pharm. Bull. 2010, 58, 464-466.

5. Su, J.-H.; Lin, Y.-F.; Lu, Y.; Yeh, H.-C.; Wang, W.-H.; Fan, T.-Y.; Sheu, J-H. Oxygenated cembranoids from the cultured and wild-type soft corals Sinularia flexibilis. Chem. Pharm. Bull. 2009, 57, 1189-1192.

6. Weinheimer, A.J.; Matson, J.A.; Hossain, M.B.; van der Helm, D. Marine anticancer agents: Sinularin and dihydrosinularin, new cembranolides from the soft coral, Sinularia flexibilis. Tetrahedron Lett. 1977, 34, 2923-2926.

7. Wen, T.; Ding, Y.; Deng, Z.; van Ofwegen, L.; Proksch, P.; Lin, W. Sinulaflexiolides A-K, cembrane-type diterpenoids from the Chinese soft coral Sinularia flexibilis. J. Nat. Prod. 2008, $71,1133-1140$.

8. Marville, K.I.; McLean, S.; Reynolds, W.F.; Tinto, W.F. New cembrane diterpenes of the marine octocoral Eunicea tourniforti from the eastern Caribbean. J. Nat. Prod. 2003, 66, 1284-1287.

9. Wei, X.; Rodríguez, A.D.; Baran, P.; Raptis, R.G.; Sánchez, J.A.; Ortega-Barria, E.; González, J. Antiplasmodial cembradiene diterpenoids from a Southwestern Caribbean gorgonian octocoral of the genus Eunicea. Tetrahedron 2004, 60, 11813-11819.

10. Alley, M.C.; Scudiero, D.A.; Monks, A.; Hursey, M.L.; Czerwinski, M.J.; Fine, D.L.; Abbott, B.J.; Mayo, J.G.; Shoemaker, R.H.; Boyd, M.R. Feasibility of drug screening with panels of human tumor cell lines using a microculture tetrazolium assay. Cancer Res. 1988, 48, 589-601.

11. Scudiero, D.A.; Shoemaker, R.H.; Paull, K.D.; Monks, A.; Tierney, S.; Nofziger, T.H.; Currens, M.J.; Seniff, D.; Boyd, M.R. Evaluation of a soluble tetrazolium/formazan assay for cell growth and drug sensitivity in culture using human and other tumor cell lines. Cancer Res. 1988, $48,4827-4833$.

12. Jean, Y.-H.; Chen, W.-F.; Sung, C.-S.; Duh, C.-Y.; Huang, S.-Y.; Lin, C.-S.; Tai, M.-H.; Tzeng, S.-F.; Wen, Z.-H. Capnellene, a natural marine compound derived from soft coral, attenuates chronic constriction injury-induced neuropathic pain in rats. Br. J. Pharmacol. 2009, $158,713-725$.

13. Jean, Y.-H.; Chen, W.-F.; Duh, C.-Y.; Huang, S.-Y.; Hsu, C.-H.; Lin, C.-S.; Sung, C.-S.; Chen, I.-M.; Wen, Z.-H. Inducible nitric oxide synthase and cyclooxygenase-2 participate in anti-inflammatory and analgesic effects of the natural marine compound lemnalol from Formosan soft coral Lemnalia cervicorni. Eur. J. Pharmacol. 2008, 578, 323-331.

Samples Availability: Not available.

(C) 2011 by the authors; licensee MDPI, Basel, Switzerland. This article is an open access article distributed under the terms and conditions of the Creative Commons Attribution license (http://creativecommons.org/licenses/by/3.0/). 